\title{
西沙海域晚中新世环礁体系的发现及演化
}

\author{
匡增桂*，郭依群，王嘹亮，梁金强，沙志涁 \\ 国土资源部海底矿产资源重点实验室，广州海洋地质调查局，广州 510075 \\ * E-mail: kzg21001@163.com
}

收稿日期: 2013-12-25; 接受日期: 2014-07-30; 网络版发表日期: 2014-11-14

国家自然科学基金项目(批准号: 91028003,41406068)和国土资源部海底矿产资源重点实验室开放基金项目(编号: KLMMR-2013-A-22)资助

\begin{abstract}
摘要前人对南海现代环礁的研究已经非常系统和深入，但对古环礁及其沉积体系的研究却 很少涉及. 本文利用高分辨二维地震数据, 在西沙海域发现了 3 个晚中新世环礁体系, 分别命名 为 $\mathrm{A}, \mathrm{B}$ 及 $\mathrm{C}$. 这 3 个环礁体系均发育于由断层控制的地垒之上，由环礁礁体、点礁、礁前斜坡 及潟湖沉积组成。在层序地层格架下, 利用礁前斜坡沉积是否发育来判定这 3 个环礁体系的淹 没史. 环礁体系 $\mathrm{A}$ 上的大型环礁礁体一直发育至第四纪才被淹没, 而环礁体系 $\mathrm{B}$ 及 $\mathrm{C}$ 在上新世 均被淹没。晚中新世, 研究区内环礁体系发育最为广泛和完整, 表明晚中新世是西沙海域造礁 生物最为繁盛的时期, 这与 ODP 184 航次钻探结果相一致; 上新世是研究区内一个重要的生物 礁淹没期，环礁体系 $\mathrm{B}$ 及 $\mathrm{C}$ 全部被淹没于海水之下，半远洋沉积开始占据优势; 第四纪是研究区 内另一个生物礁淹没期, 环礁体系 $\mathrm{A}$ 上的两个大型环礁最终被淹没于海底之下, 半远洋沉积开 始覆盖填平晚中新世形成的环礁体系。环礁的生长与淹没长期来看主要受构造沉降控制, 而全 球海平面升降在短期的某一时段内也会产生影响.
\end{abstract}

关键词

西沙海域 环礁体系 发现 淹没 演化
南海的现代环礁主要分布在西沙、中沙、东沙以 及南沙群岛, 最早的一些研究主要集中在环礁的类 型、地貌特征以及沉积相带的研究(曾昭璇, 1982, 1984; 曾昭璇和丘世钧, 1985; 黄金森, 1987; 王国忠 等, 1988). 随后对南海生物礁的研究逐渐分为两个方 向: 一是现代生物礁对环境及气候变化的记录(聂宝 符等, 1996; Wei 等, 2000; 赵焕庭等, 2000; $\mathrm{Yu}$ 等, $2004 a, 2004 b$; 余克服, 2012); 二是古生物礁及其相 关的碳酸盐台地特征及含油气性. 至今南海已经发 现 30 多个生物礁油气田(赵强, 2010), 古生物礁作为 一种重要的油气储层而备受关注, 对古生物礁的研 究主要集中在各类生物礁的地震反射特征(马玉波等, 2009a; $\mathrm{Wu}$ 等, 2009; 黄鸿光等, 2012; 马玉波等, 2010; Ma 等, 2011; 杨涛涛等, 2011)以及发育演化模 式(马玉波等，2009b; 吴时国等，2009; 马玉波等， 2011).

前人对南海现代环礁的研究已经非常深入系统, 对古生物礁的地震反射特征研究也非常成熟, 但是 对特定的古环礁及其沉积体系的研究却很少涉及, 这主要与古环礁早已没入水下并被后期沉积所覆盖, 资料难以收集有关. 本文通过高分辨率二维地震资 料的精细解释, 在西沙海域发现了 3 个晚中新世环礁 体系, 并研究了其内部地震相特征及空间配置关系, 在层序地层框架下分析其时空演化过程. 由于环礁对

中文引用格式: 匡增桂, 郭依群, 王嘹亮, 等. 2014. 西沙海域晚中新世环礁体系的发现及演化. 中国科学: 地球科学, 44: 2675-2688

英文引用格式: Kuang Z G, Guo Y Q, Wang L L, et al. 2014. Evolution of the Late Miocene atoll systems offshore Xisha Islands. Science China: Earth Sciences, 57: 3084-3096, doi: 10.1007/s11430-014-4962-9 
海平面具有指向意义, 因此本次研究将为研究南海相 对海平面变化、裂后沉降等问题提供新思路.

\section{1 地质概况}

研究区位于西沙群岛东北部海域(图 1), 北为西 沙海槽, 东南角嵌入双峰南盆地, 正常海底水深从 $1300 \mathrm{~m}$ 逐渐加深至 $3450 \mathrm{~m}$ (被溺的大型环礁水深仅为 $350 \mathrm{~m})$. 构造位置处于西沙隆起东北端, 大地构造隶 属于中-西沙地块. 中-西沙地块原与华南地块相连, 晚白严世-早渐新世南海北部经历了伸展裂陷, 中-西 沙地块由于刚性特征而在其南北两侧发育了两个深 裂陷槽; 晚渐新世陆壳开始发生破裂, 沿着中西沙北
侧深裂陷槽西北次海盆开始扩张, 中-西沙地块与华 南地块裂离, 并不断南移; 早-中中新世西北次海盆 扩张脊被废弃, 新扩张脊在南侧形成, 并向西延伸至 西南次海盆, 此时位于西南次海盆北侧的中-西沙地 块逐渐停止移动, 并进入裂后热沉降期(Briais, 1993; 孙珍等, 2009).

在整个东南亚地区, 至少有 6 个区域在新生代发 育了大量的碳酸盐沉积, 这 6 个区域包括苏门答腊岛 弧前及弧后地区; 爪哇岛弧前及弧后地区; 婆罗洲东 北、西北和东部边缘以及中国的南沙群岛; 印尼东部 地区; 菲律宾及南海北部陆缘; 新几内亚地区(Wilson, 2002). 这些发育于不同构造及沉积背景的碳酸盐体 系表明南海及其周边地区新生代以来有着非常繁盛

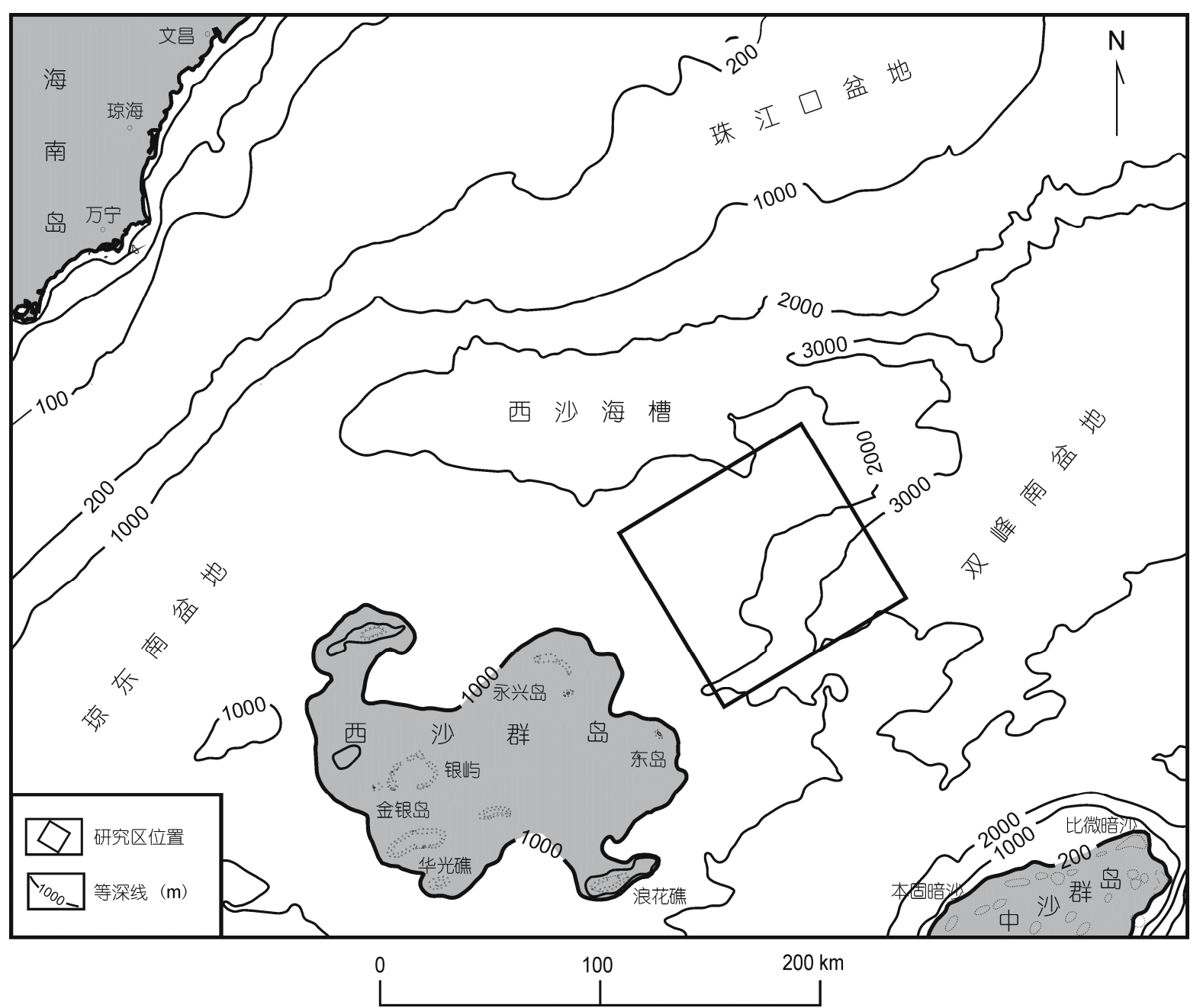

图 1 研究区地理位置图 
的碳酸盐沉积过程. 南海关于碳酸盐沉积的基础资 料主要来自于 ODP 184 航次的钻探, 其成果揭示了 南海北部陆坡 3 个重要的沉积历史阶段: 渐新世高速 堆积期, 中新世与早上新世高碳酸盐含量的低速堆 积期, 和近 $3 \mathrm{Ma}$ 以来的低碳酸盐含量的高陆源碎屑 堆积期(Wang 等, 2000). 这一结果表明在南海北部, 中新世至早上新世为碳酸盐沉积的繁盛时期, 特别 是在晚中新世 $(10 \sim 5 \mathrm{Ma})$, 碳酸盐沉积达到了顶峰, ODP 184 航次位于现代溶越面之上的两个站位(1143 和 1146)晚中新世的岩心中, 碳酸盐含量均高达 50\%, 这一现象被认为与发生在同一时期的赤道太平洋地 区的“生物勃发”有关(Wang 等, 2000; Li 和 Wang, 2009), 由于“生物勃发”带来了巨大的生物生产力, 大大提高了碳酸盐的输入量, 从而使得晚中新世成 为南海北部最为显著的一个高碳酸盐供给时期.

西沙海域从中新世开始, 就进入大规模成礁时 期, 2000 多万年来, 始终保持成礁环境, 永兴岛上的 西永 1 井揭示了 $1251 \mathrm{~m}$ 的礁相地层(何起祥和张明书, 1986). 赵强(2010)根据地震资料解释及层序地层研 究, 认为西沙海域碳酸盐台地的发育演化分为 4 个期 次: 早中新世为碳酸盐台地初始形成时期; 中中新世 为碳酸盐台地广泛发育时期; 晚中新世为碳酸盐台 地发育后退和萎缩期; 上新世以后为碳酸盐台地的 淹没期.

\section{2 晚中新世以来层序地层格架}

本次研究主要利用了 2011 年广州海洋地质调查 局在西沙海域采集的高分辨率二维地震数据. 地震 采集参数为: 震源容量为 $560 \mathrm{in}^{3}\left(1 \mathrm{in}^{3} \approx 1.639 \times 10^{-5}\right.$ $\mathrm{m}^{3}$ ), 接收道数为 240 道, 炮间距 $25 \mathrm{~m}$, 道间距 $12.5 \mathrm{~m}$, 采样率为 $1 \mathrm{~ms}$.

研究区内没有钻井资料, 本次研究主要是根据 琼东南盆地层序划分方案(赵强, 2010; 马玉波等, 2010)并参考了前人研究成果(袁胜强, 2009), 再结合 地震反射特征来进行层序界面的识别, 建立了研究 区内晚中新世以来的层序地层格架, 共识别出 3 个三 级层序界面 T1, T2 及 T3(图 2), 分别对应于第四纪、 上新世及晚中新世的底界.

$\mathrm{T} 1$ 界面为一个典型的上超界面(图 2), 地层厚度 向构造隆起区明显减薄, 该界面之下为一套弱-中振 幅、高频近平行状反射, 界面之上为一套中-强振幅、 高频近平行状反射. T2 界面仍表现为一个上超界面 (图 2), 地层厚度同样向构造隆起部位减薄, 该界面 之下为一套强振幅、低频近平行状反射, 界面之上为 一套弱振幅、高频近平行状反射. T3 界面表现为一个 上超下削界面(图 2), 该界面之上为一套强振幅、低 频近平行状反射, 界面之下为一套强振幅、低频倾斜 状反射. T3 界面强烈削截下伏地层, 表明在中中新世

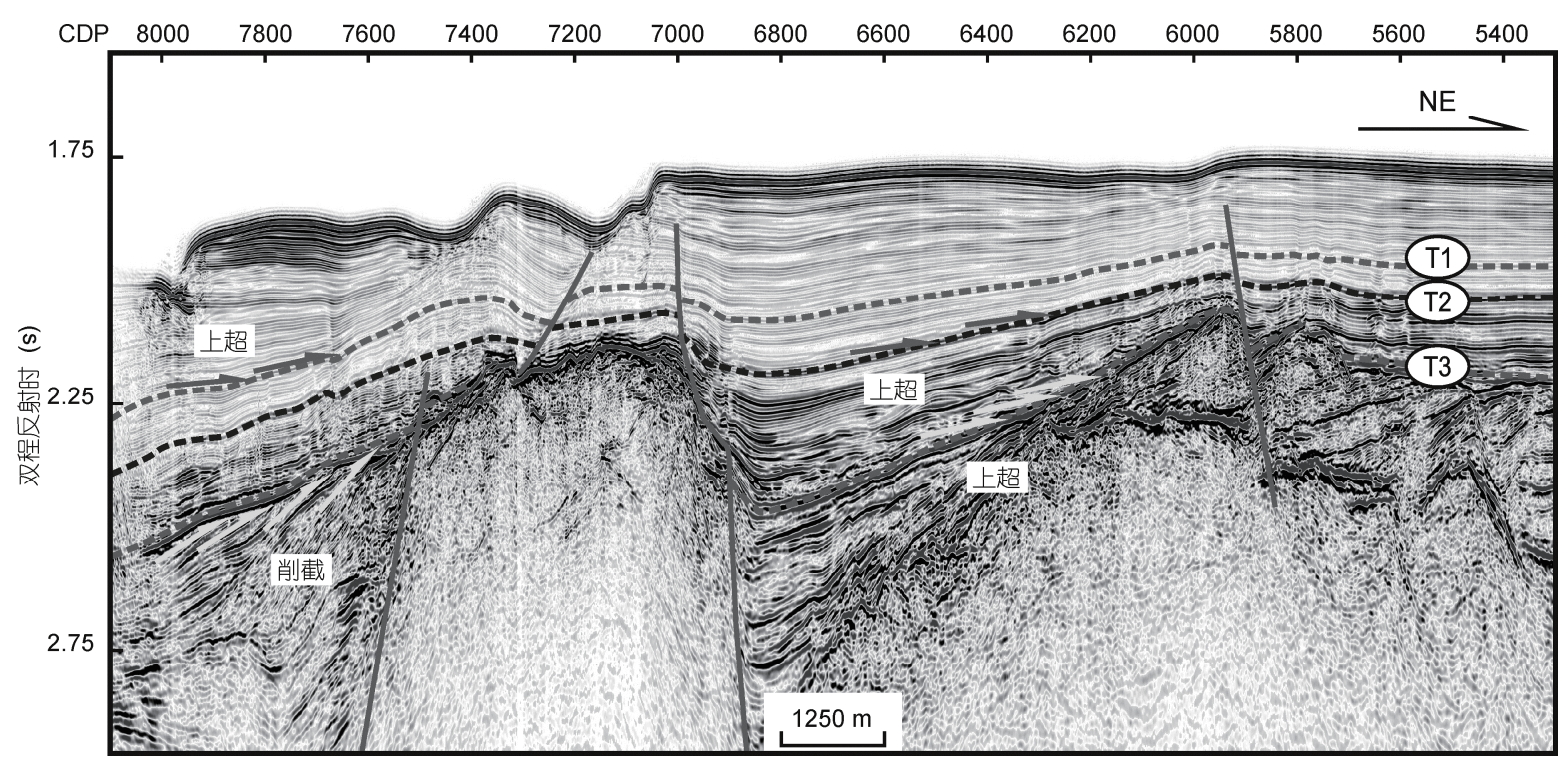

图 2 研究区层序地层格架 
晚期研究区有可能暴露出水表, 并遭受剥蚀, 这也说 明在中中新世晚期研究区内水深总体可能较浅, 这 为碳酸盐沉积及生物礁的生长发育提供了一个良好 的沉积环境.

\section{3 环礁体系的地震相特征}

\section{1 碳酸盐台地及点礁}

如图 3 所示, T3 界面之下发育了一个典型的碳酸 盐台地, 形态上具有平坦宽阔的顶部及由断裂形成 的陡峭边缘, 台地正好发育于两侧正断层形成的地 垒之上, 受断层控制明显, 这些特征与 $\operatorname{Read}(1985)$ 定 义的碳酸盐台地相吻合. 地震相特征主要表现为顶 部呈强反射, 表明上下地层之间的物性差异, 内部为 空白反射, 说明台地内部的物质较为均一.
碳酸盐台地的地形总体表现为两端较高而中间 下凹(图 3), 两端较高的部位经历了碳酸盐建隆, 为 环礁礁体发育的位置, 中间下凹的部分为环礁礁体 限制的潟湖，在潟湖内发育了一系列小规模的丘状 反射体(图 3), 这些丘状反射体内部呈强振幅断续反 射, 为发育于潟湖之内的点礁. 点礁一般发育于潟湖 或滨外海底上的浅水区(刘宝珺，1980), 是浅水沉积 的典型标志, 表明当时的海平面就在点礁所发育的 位置附近.

\section{2 环礁礁体及礁前斜坡}

如图 4 所示, 在研究区的西北角发育大型环礁礁 体. 从外部形态来看, 环礁礁体具有近水平的顶及陡 峭的边缘，发育于由断层控制的地垒之上，通常被认 为是由于相对海平面快速上升, 大多数的生物礁被

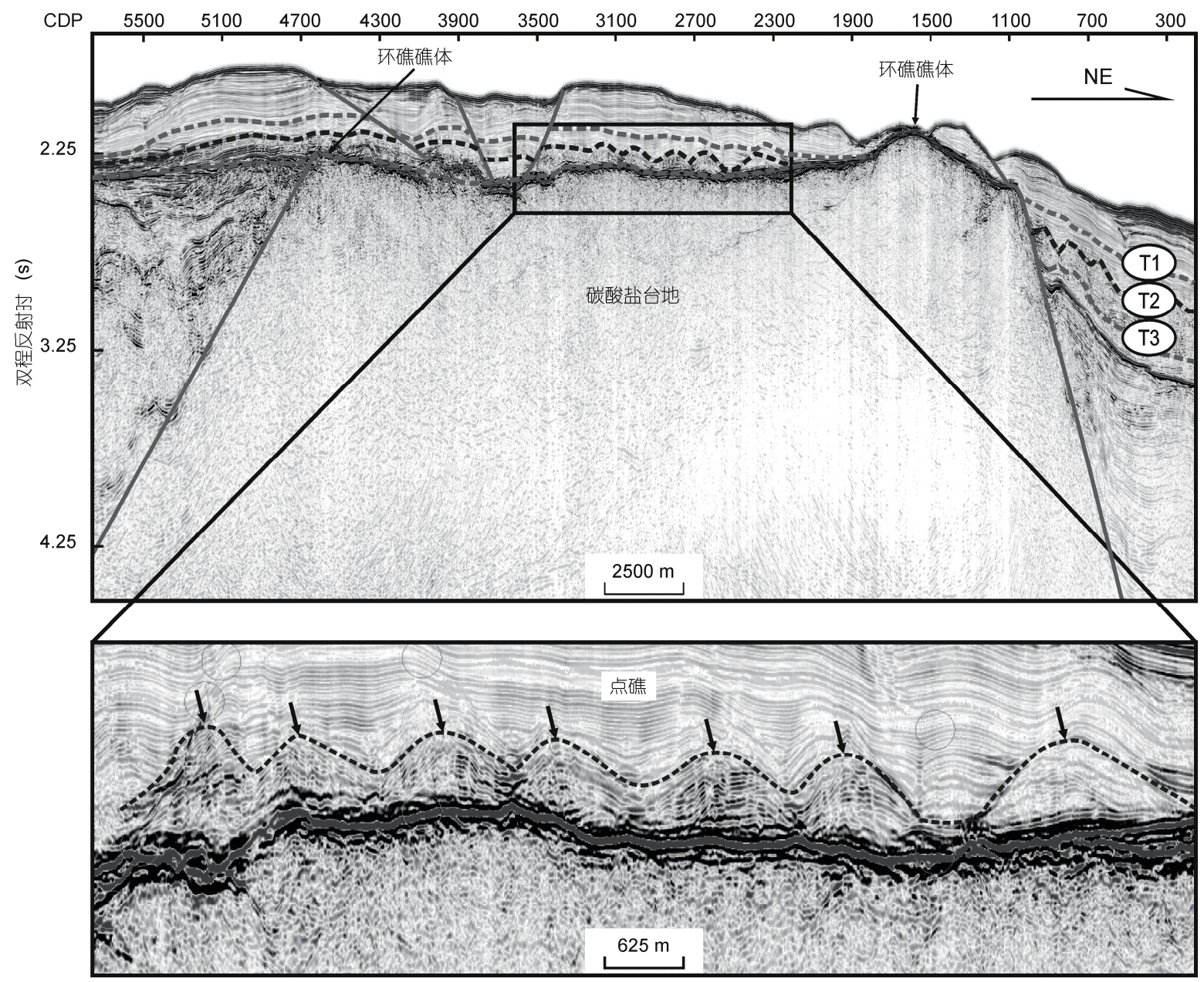

图 3 碳酸盐台地及点礁地震相特征 
淹没, 而只有发育于构造高地上的生物礁能保持持 续生长, 生长速率与相对海平面上升速率大致持平, 最后逐渐形成高出海底数千米的大型环礁礁体(Ma 等, 2011). 地震反射主要表现为顶部呈强反射, 内部 以空白反射为特征(图 4). 在环礁礁体的顶部出现喀 斯特地貌特征, 表明该礁体曾一度暴露于海面而接 受雨水的风化淋滤.

在环礁礁体的向海一侧发育了礁前斜坡沉积(图 4), 礁前斜坡沉积主要发育于孤立碳酸盐台地或环礁 向海一侧的斜坡, 由重力流带来的浅水碳酸岩碎屑 是礁前斜坡的主要沉积物, 其最主要的标志是含有 礁灰岩岩块的沉积角砾楔状体(姜在兴, 2003). 如图 4
所示, 礁前斜坡沉积外部形态呈楔状, 沉积厚度随着 远离环礁而逐渐变薄, 内部反射主要为连续的强振 幅前积反射.

\section{3 环礁礁体及潟湖}

如图 5 所示, 环礁礁体发育于两侧正断层形成的 地垒之上，在两个环礁礁体之间由于断层的发育而 下凹形成潟湖. 从地震剖面来看, 晚中新世潟湖内沉 积外形呈楔状, 并强烈削截下伏地层, 表明沉积物主 要为从环礁礁体上通过重力流搬运下来的生物礁碎 屑, 内部反射主要为连续的中强振幅上超反射, 表明 沉积物沿着潟湖斜坡逐渐堆积的过程.一般来说潟

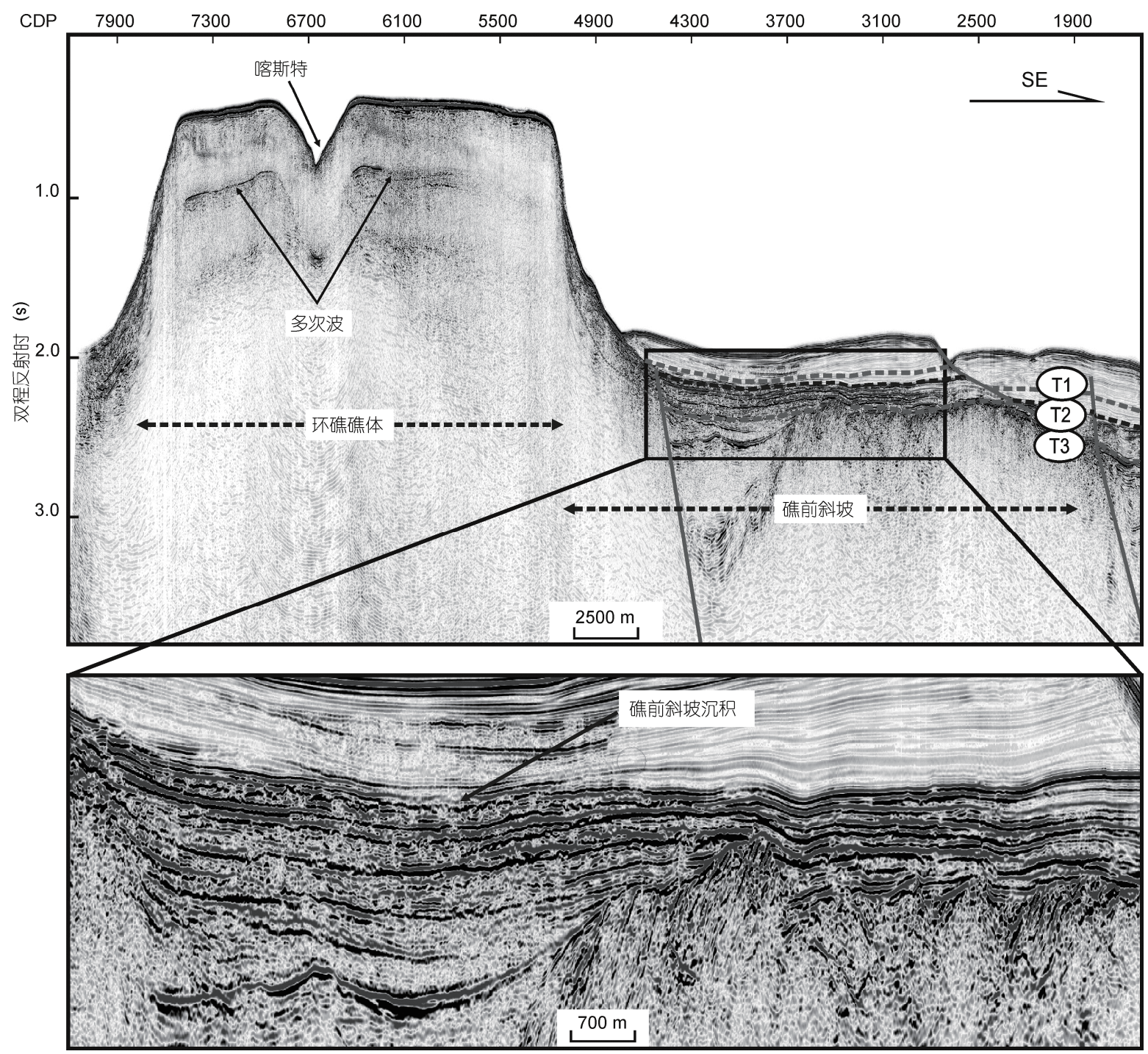

图 4 大型环礁礁体及礁前斜坡沉积地震相特征 


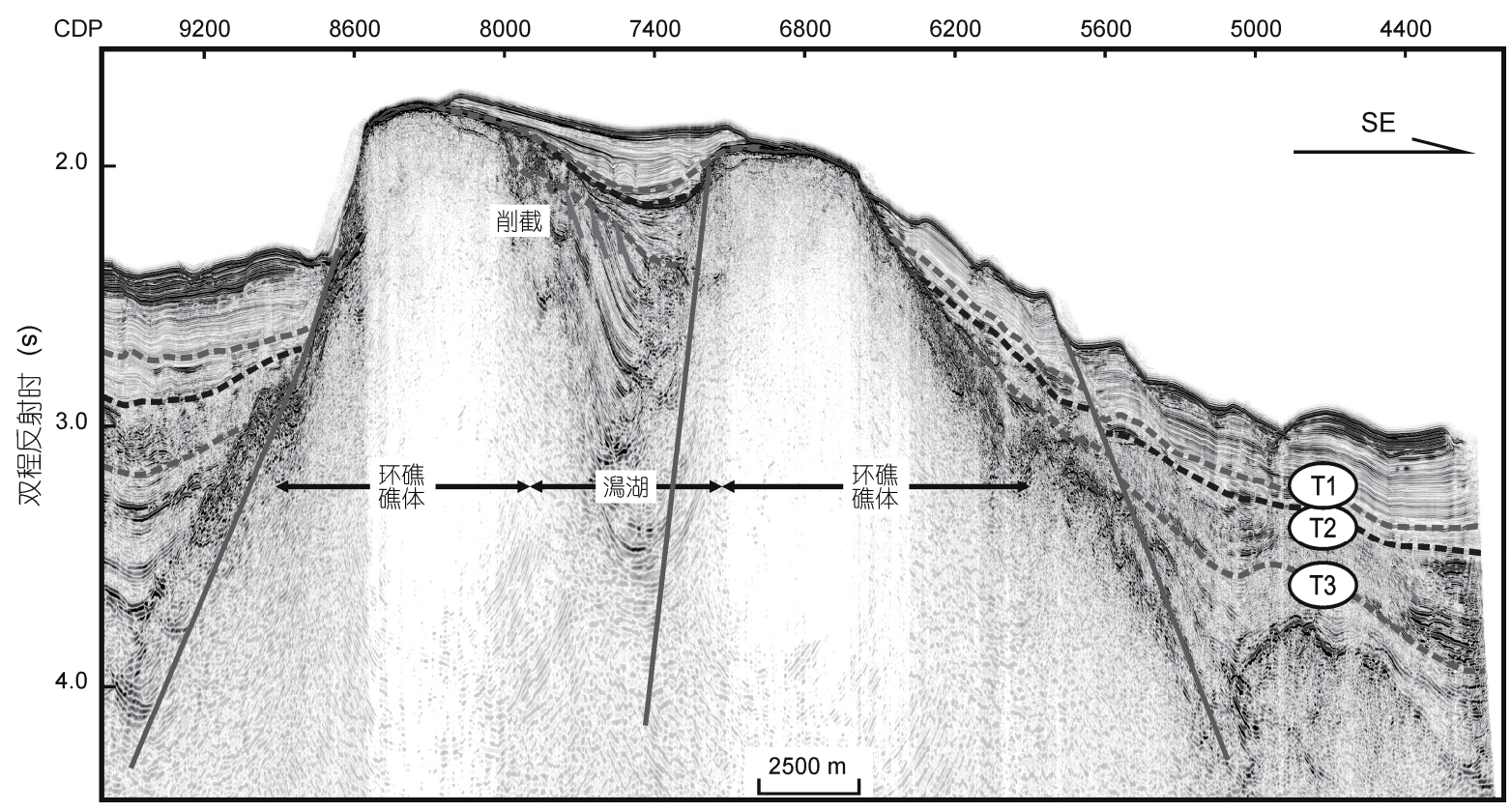

图 5 环礁礁体及潟湖沉积地震相特征

湖是局限的低能地带, 通常以细粒沉积物为主, 但如 果潟湖面积狭小, 生物礁碎屑沉积将占据优势.

\section{4 深海碳酸盐沉积}

在 T2 与 T3 界面之间, 即晚中新世地层内广泛发 育了一种非常独特的地震相单元, 主要表现为强-中 振幅, 同相轴非常不连续, 整体表现为似平行反射的 特征(图 6), 这种地震反射特征与南海 ODP 184 航次 的 1148 站位的渐新统-下中新统地震相极为相似(图 7). 1148 站位渐新世至早中新世地层的岩性总体上为 含有孔虫的超微化石软泥及黏土, 但是在渐新世的 层段内具有非常高的碳酸盐堆积速度, 至渐新世晚 期, 碳酸盐含量突然增高, 达到 50\% 70\%, 岩性也由 白严代替了黏土, 这一岩性变化在地震剖面表现为 一个明显的强振幅反射(图 7), 而在早中新世, 碳酸 盐沉积也以白严黏土为代表, 平均碳酸盐含量也达 到 35\%(Wang 等, 2000). 1148 站位岩性与地震相的对 比表明, 这种强-中振幅、不连续的似平行反射可能与 地层中的碳酸盐沉积有关, 强-中振幅可能是由于沉 积层中高碳酸盐含量导致的, 同相轴的不连续可能 是由于碳酸盐在地层中分布不均引起的, 而似平行 反射则表明沉积层仍以半远洋沉积为主. 根据这一 推断, 研究区内晚中新世地层也可能存在较高的碳 酸盐含量.
另外, 如前所述, 晚中新世是南海北部最为显著 的一个高碳酸盐供给时期, 1143 和 1146 站位晚中新 世碳酸盐含量均高达 50\%, 深水区的 1148 站位也超 过了 30\%(Wang 等, 2000), 这进一步说明研究区内晚 中新世可能存在深海碳酸盐沉积.

\section{4 环礁体系的分布及形态}

西沙海域从中新世开始, 就进入大规模成礁时 期, 但后期经历了长时间的热沉降, 现今研究区内的 所有生物礁都已没入水下, 其上覆盖了后期的半远 洋碎屑沉积, 如果将碳酸盐台地及生物礁也看作盆 地基底, 将覆盖其上的半远洋沉积剥离, 做盆地基底 即碎屑沉积底界面的等 T0 图, 可以很好的揭示研究 区内环礁体系的分布及发育形态.

如图 8 所示, 研究区内发育了 3 个环礁体系 $\mathrm{A}, \mathrm{B}$ 及 $\mathrm{C}$, 环礁体系主要分布在断层控制的地垒之上, 其 间由位于断层上盘的深凹占据. 这 3 个环礁体系规模 不等、成熟度不一. 环礁体系 $\mathrm{A}$ 面积约为 $1423 \mathrm{~km}^{2}$, 发育于受断层控制的碳酸盐台地之上(图 3), 其上发 育 2 个大型环礁礁体(图 4,8,9和 10)、4 个小型环礁 礁体(图 3，8), 大型环礁礁体外侧发育明显的礁前斜 坡沉积(图 4, 9 和 10), 中间发育宽广的潟湖, 潟湖内 发育点礁(图 3), 环礁规模大且基本成型, 潟湖封闭 


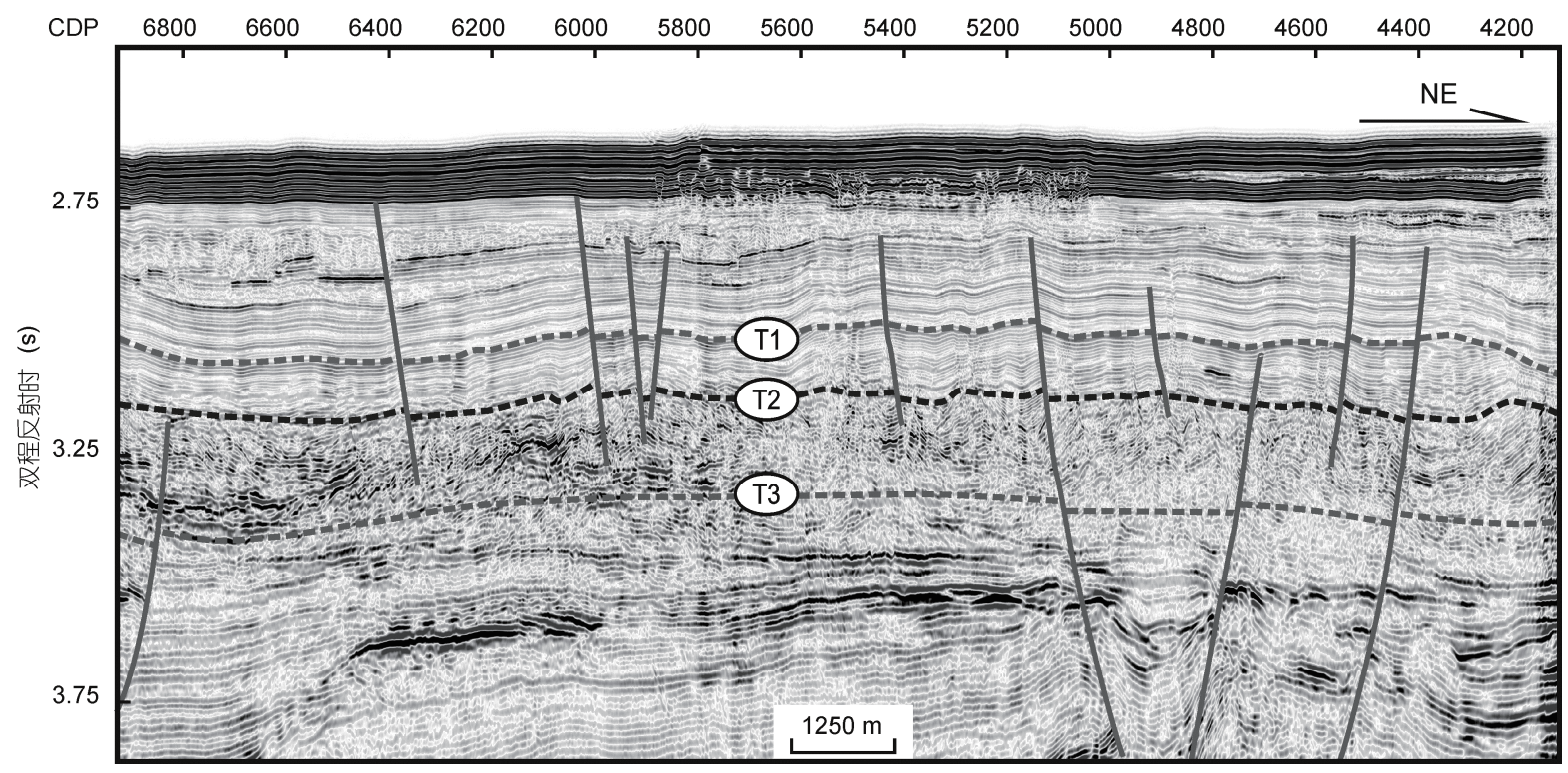

图 6 晚中新世(T3-T2)深海碳酸盐沉积地震反射特征

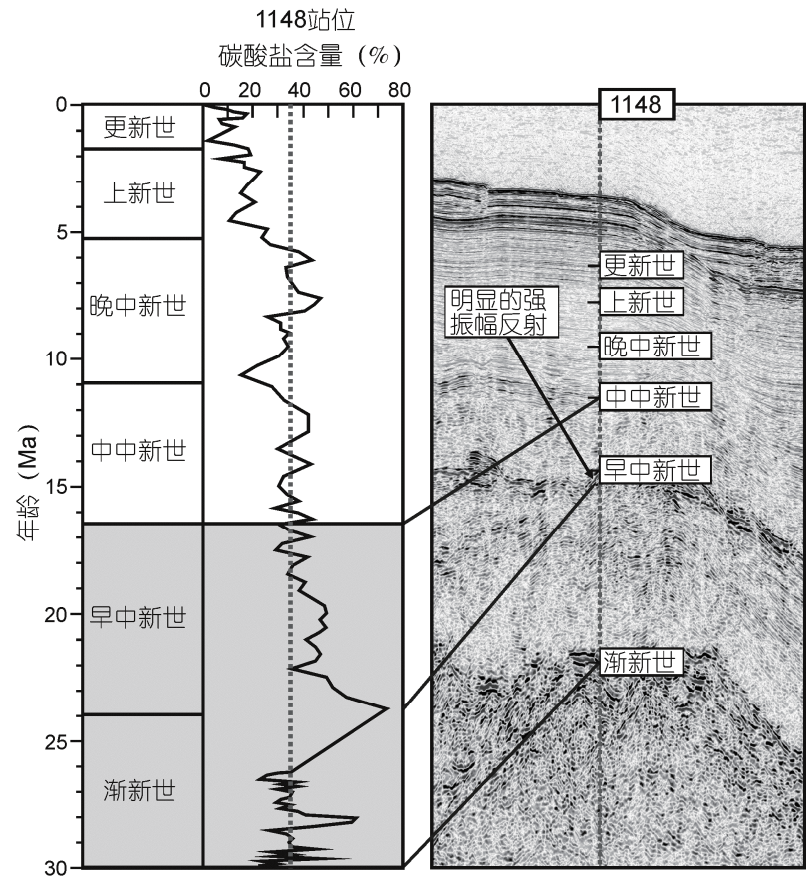

图 71148 站位渐新世-早中新世碳酸盐含量及地震相

1148 站位碳酸盐含量数据来源于 ODP184 航次报告

良好但也存在数个通道, 为处于壮年期的环礁体系; 环礁体系 B 面积约为 $420 \mathrm{~km}^{2}$, 同样发育于受断层控 制的碳酸盐台地之上(图 11), 主要发育了 4 个小型环 礁礁体(图 8 和 11), 也发育潟湖, 潟湖内发育点礁(图 11), 但这个环礁体系相对规模较小, 潟湖封闭性较
差，通道过于宽广，为处于幼年期的环礁体系; 环礁 体系 C 面积约为 $240 \mathrm{~km}^{2}$, 主要由 2 个近东西向的大 型环礁礁体封闭而成(图 5), 潟湖面积狭小, 且只存 在西面的 1 个通道, 这是成熟环礁体系的典型标志, 为处于老年期的环礁体系.

\section{5 环礁体系的淹没}

生物礁在生长过程中, 由波浪带来的养分是不可 或缺的因素, 因此生物礁主要发育在水体循环良好的 地区，但是波浪在带来养分的同时，也会对生物礁体 产生破坏作用, 被波浪击碎的生物礁碎块在重力流作 用下, 被带至礁前斜坡甚至更远的地方沉积下来, 形 成特殊的礁前斜坡沉积, 但是当相对海平面快速上升, 并且上升速率大于生物礁的生长速率时, 就会发生溺 礁事件, 生物礁停止发育并没入水下, 水动力条件减 弱，礁前斜坡沉积也随之不再发育，因此礁前斜坡沉 积是否发育可以用于判定生物礁的淹没史.

如前所述，礁前斜坡沉积在地震剖面上主要表 现为楔状的连续强振幅前积反射，极易识别. 环礁体 系 A 主要发育大型环礁礁体，且均存在礁前斜坡沉 积, 如图 9 所示, 在大型环礁礁体 I 的北东侧就发育 了一套这样的沉积体, 虽然由于环沟的发育, 影响了 整套沉积体的厚度，但是通过地震层序对比，发现这 套沉积体在 T3 界面之上的所有地层中均有分布, 这 


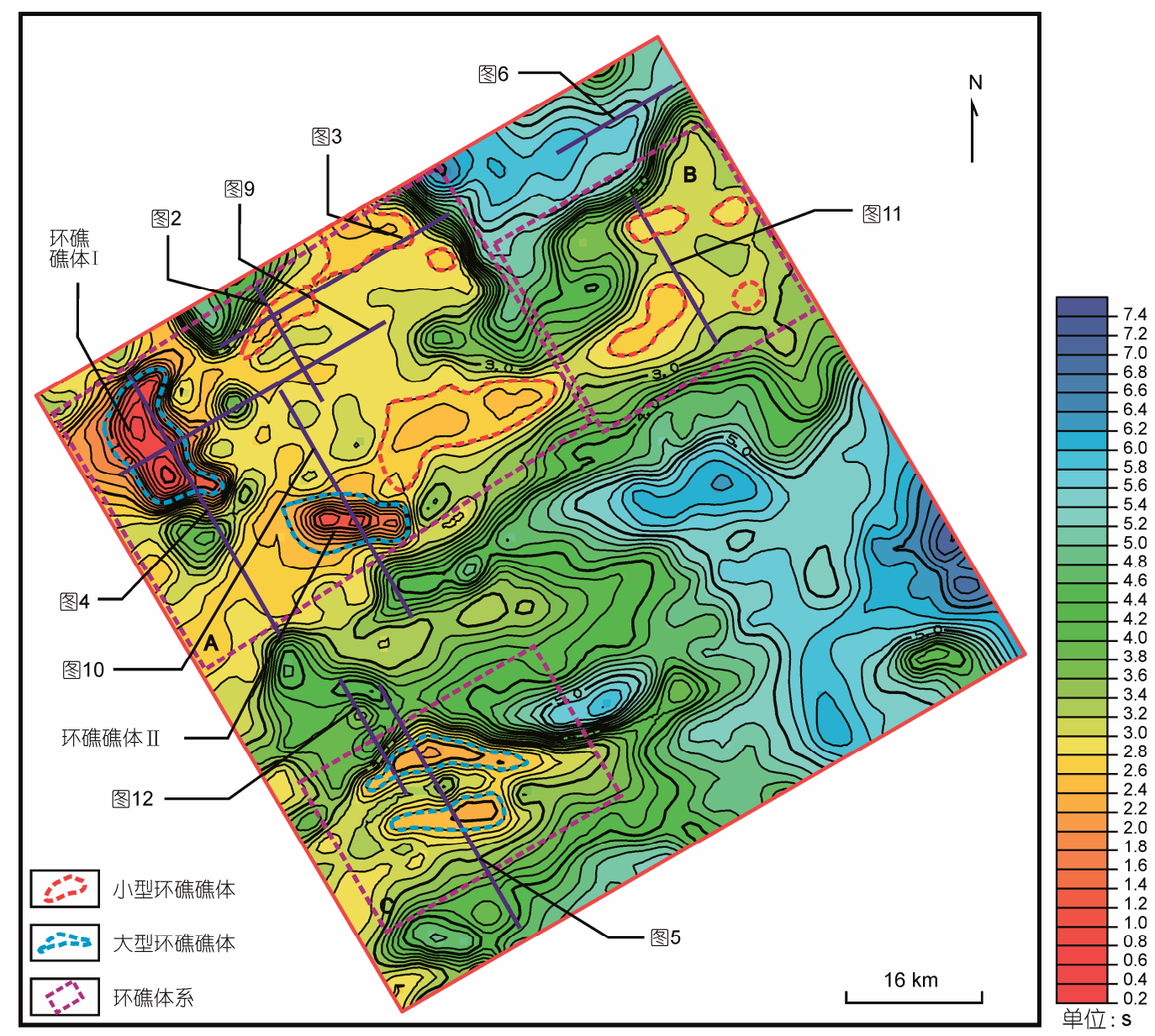

图 8 碎首沉积底界面等 T0 图及各剖面位置

注意环礁体系的分布及形态

表明大型环礁礁体 I 持续生长至第四纪, 才在第四 纪内的某个相对海平面快速上升期被淹没, 现今水 深在 $350 \mathrm{~m}$ 左右. 图 10 所示的环礁体系 A 上的另一个 大型环礁礁体 II 具有类似的特征, 而且由于环沟不发 育, 礁前沉积展示的更为清楚, 因此台地 $\mathrm{A}$ 上的两个 大型环礁礁体 I, II 均发育至第四纪后才被淹没.

环礁体系 B 主要发育小型环礁礁体. 如图 11 所 示, 碳酸盐台地同样受控于两侧的正断层, 整个环礁 体系发育于台地之上, 以小型环礁礁体为主, 而潟湖 内发育一系列点礁, 强振幅的礁前斜坡沉积规模较 小, 且只发育在环礁礁体外侧的晚中新世地层中, 这 表明这些礁体在上新世已被淹没.

环礁体系 C 主要发育大型环礁礁体(图 5 和 12), 礁前斜坡沉积与环礁体系 $\mathrm{B}$ 类似, 只存在于晚中新 世地层中(图 12), 上新统往上均不发育, 因此环礁体
系 $\mathrm{C}$ 也在上新世被淹没.

\section{6 环礁体系的时空演化}

晚中新世时期, 研究区内主要发育了环礁体系 及深海碳酸盐沉积(图 13(a)), 环礁体系主要占据了 断层控制的构造高部位, 而深海碳酸盐沉积则广泛 分布于 3 个环礁体系之间的区域. 这时的环礁体系发 育的最为广泛和完整, 表明晚中新世是西沙海域造 礁生物最为繁盛的一个时期, 具有非常高的碳酸盐 供给能力, 从而为形成大范围的深海碳酸盐沉积提 供了物质来源, 这也印证了 ODP 184 航次的钻探结 果. 3 个环礁体系中以 $\mathrm{A}$ 最为发育, 与之相关的沉积 单元也最完整, 向海一侧主要发育了大范围的礁前 斜坡沉积, 内侧则发育了宽广的潟湖沉积, 点礁集中 
发育在潟湖的东侧并且远离大型环礁礁体, 这可能 是因为大型环礁礁体周围重力流较为发育而不适宜 点礁的生长. 大型环礁礁体 I 与 II 之间发育潟湖通 道(图 14), 潟湖通道在剖面上呈宽缓的 U 型, 切断了 环礁礁体东南侧连续的礁前斜坡沉积, 并缺失晚中 新世以来的所有沉积, 表明存在水流的侵蚀作用. 另 外, 潟湖通道发育在环礁的西南侧, 表明海水曾在西 南-东北风向的带动下与潟湖发生水体交换, 说明西
南侧为环礁的迎风面, 这也解释了西南侧生物礁及 礁前斜坡沉积特别发育的原因(图 13(a)). 环礁体系 B 规模较小, 潟湖范围也不大, 但是点礁却比较发育. 环礁体系 $\mathrm{C}$ 发育的最为成熟, 潟湖被局限一个非常 狭小的范围, 几乎没有通道与外海连接, 可能正处于 淤浅的过程之中.

上新世主要发育了大型环礁礁体、礁前斜坡沉积 及半远洋沉积(图 13(b)). 如前所述, 上新世是研究区

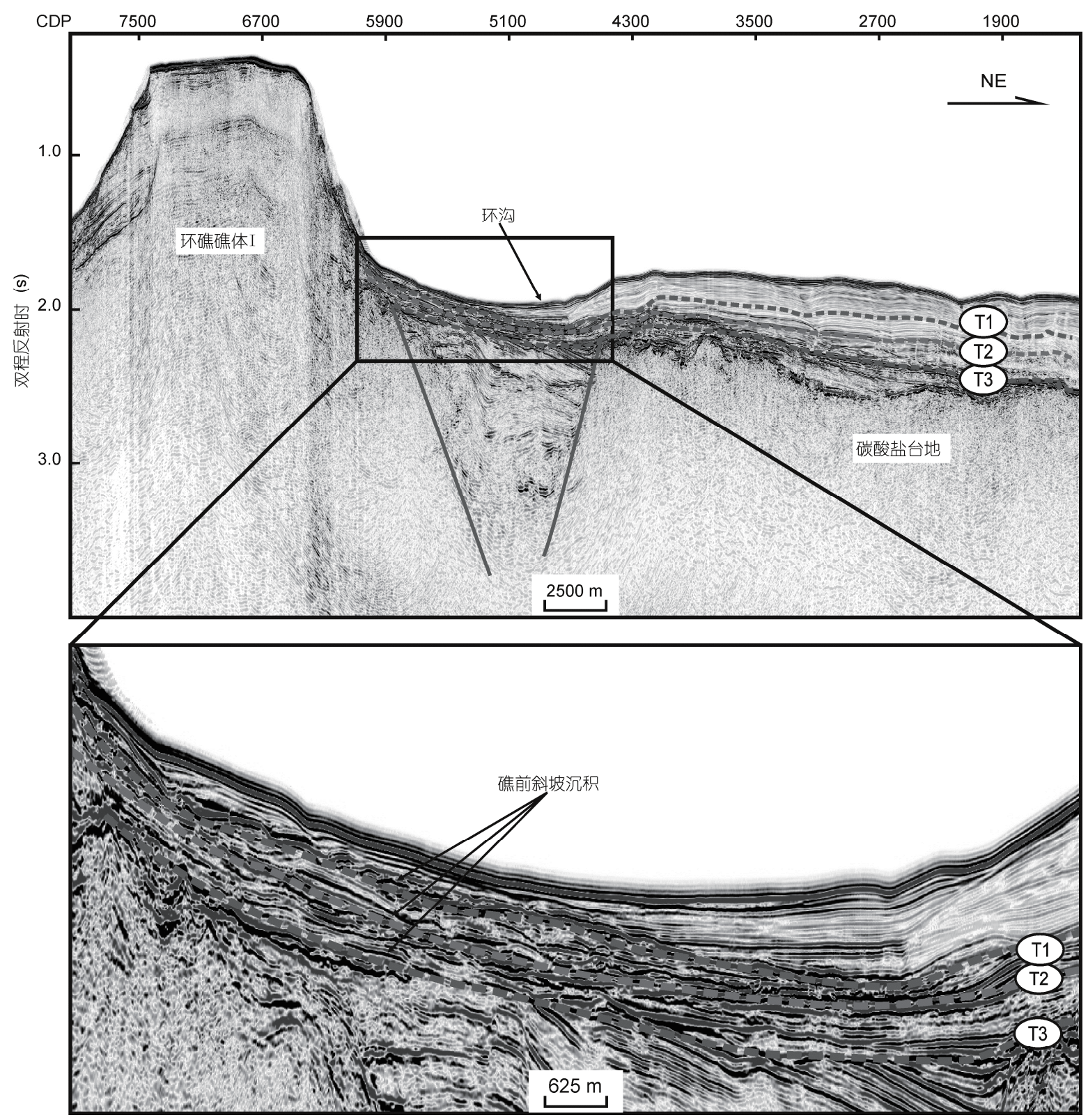

图 9 大型环礁礁体 I 的淹没

注意礁前斜坡沉积从 $\mathrm{T} 3$ 界面持续发育至海底, 这表明大型环礁礁体 I 直到第四纪才被淹没. 位置见图 8 


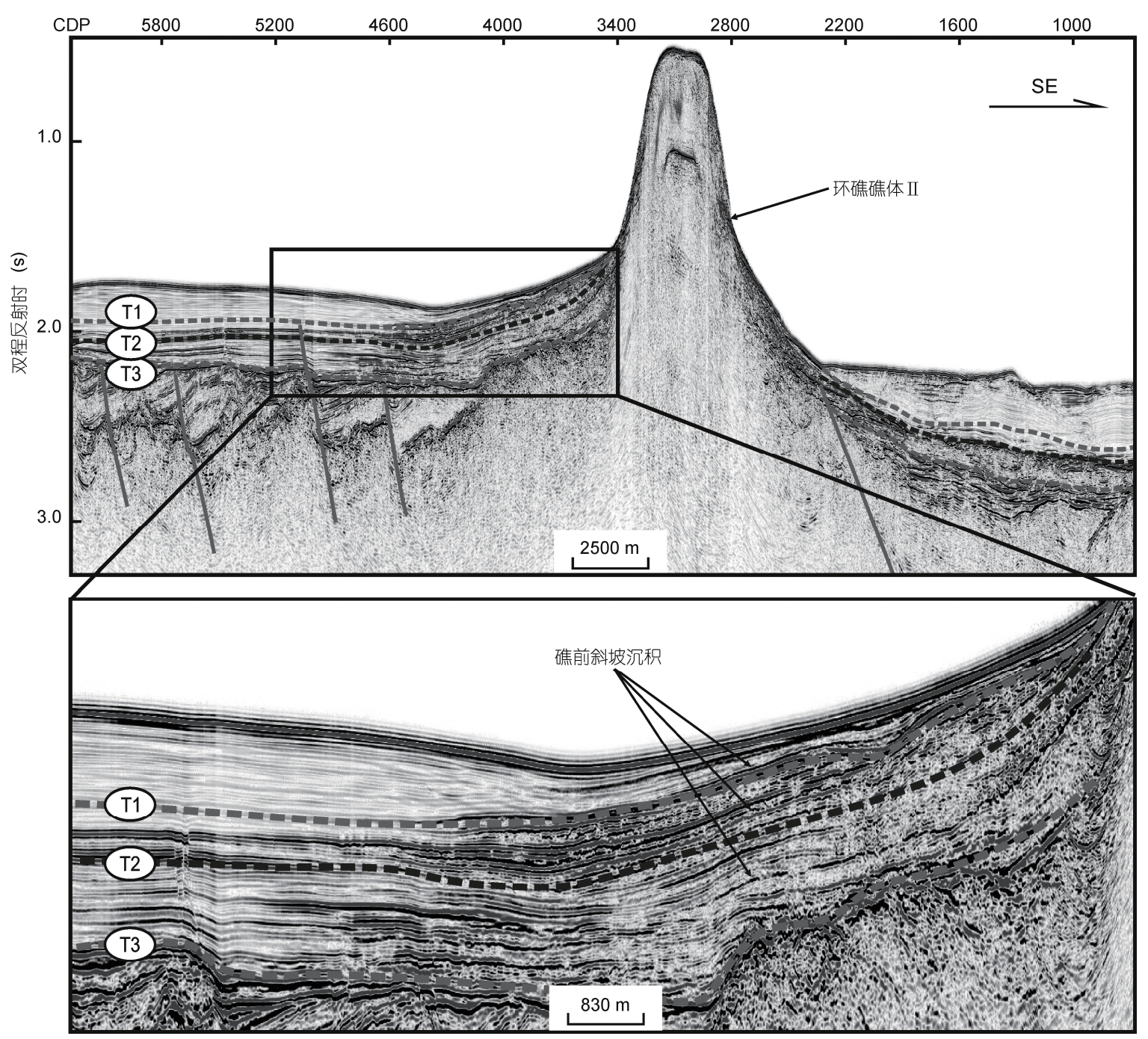

图 10 大型环礁礁体 II 的淹没

注意礁前斜坡沉积从 $\mathrm{T} 3$ 界面持续发育至海底, 这表明大型环礁礁体 II 直到第四纪才被淹没. 位置见图 8

内一个重要的生物礁淹没期, 环礁体系 $\mathrm{B}$ 及 $\mathrm{C}$ 全部被 淹没于海水之下, 但此时仍有部分生物礁体高出海 底, 因此缺失了上新世沉积, 只有环礁体系 A 上的两 个大型环礁礁体持续发育, 并在周围形成较大范围 的礁前斜坡沉积, 但相比晚中新世规模有所下降, 另 外环礁体系 A 晚中新世广泛发育的潟湖也由于东侧 的环礁礁体被淹没而被大范围的半远洋沉积所取代.

第四纪主要发育了大型环礁礁体、礁前斜坡沉积 及半远洋沉积(图 13(c)). 第四纪是研究区内另一个 生物礁淹没期, 环礁体系 $\mathrm{A}$ 上的两个大型环礁礁体 现今水深在 $350 \mathrm{~m}$ 左右, 但在第四纪某个时期内仍在 继续生长, 形成的礁前斜坡沉积分布在很小的范围
内, 表明生物礁的生长发育逐渐萎缩停止, 最终在第 四纪的某个时期淹没于海底之下. 半远洋沉积逐渐 扩大范围, 并开始覆盖充填环礁体系 B, C 内晚中新 世发育的生物礁, 沉积缺失的范围进一步缩小.

研究区内晚中新世发育的环礁、点礁及其相关的 沉积单元, 都属于浅水沉积的典型标志, 且点礁的位 置大致能代表了当时海平面的位置, 而从图 3 可以粗 略推算出埋藏的点礁离现今海平面的深度, 如果点 礁及上覆沉积层中地震波速平均按 $1700 \mathrm{~m} \mathrm{~s}^{-1}$ 计算, 水中地震波速平均按 $1500 \mathrm{~m} \mathrm{~s}^{-1}$ 计算, 点礁离现今海 平面深度为 $1804 \mathrm{~m}$, 这一结果表明, 研究区所在海 域晚中新世至现今的相对海平面上升了 $1804 \mathrm{~m}$. 相 


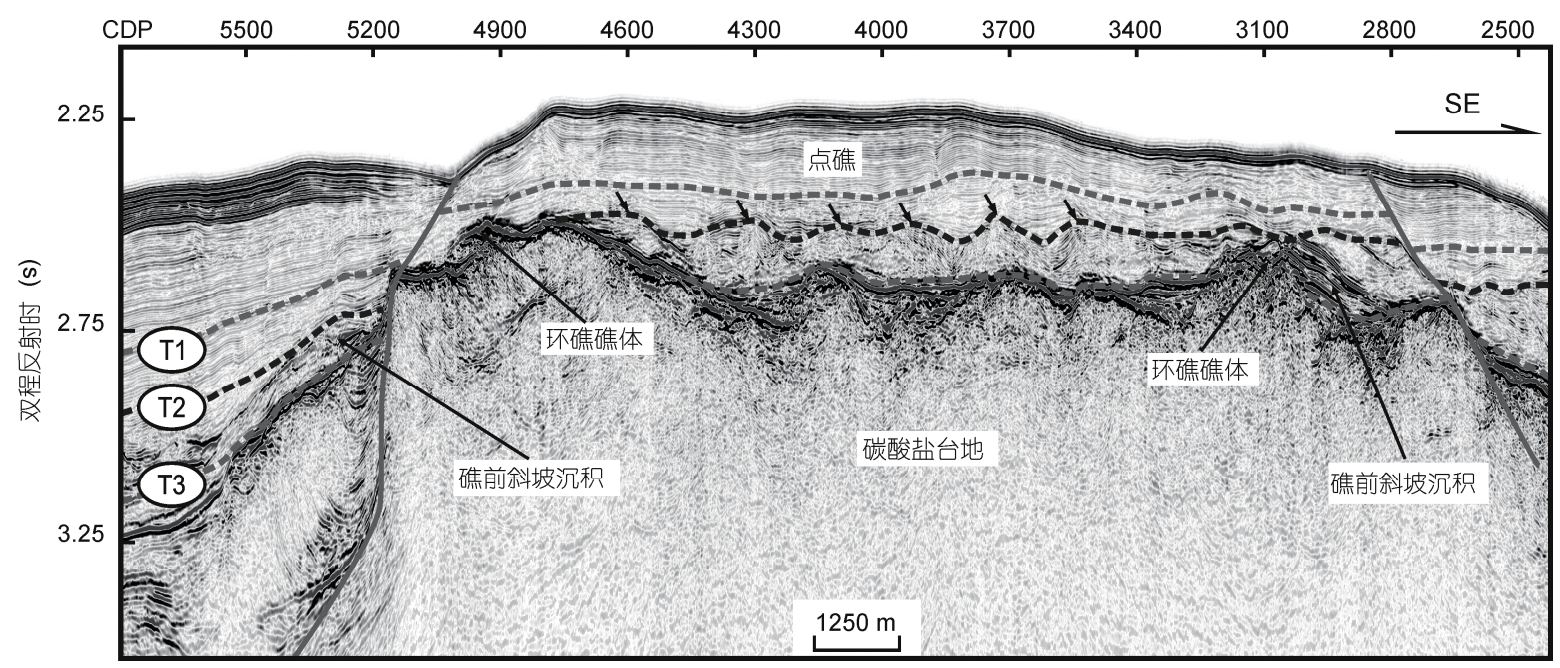

图 11 环礁体系 $\mathbf{B}$ 的淹没

注意礁前斜坡沉积只发育于 $\mathrm{T} 3$ 与 $\mathrm{T} 2$ 界面之间的地层中, 这表明环礁体系 $\mathrm{B}$ 在上新世就被淹没. 位置见图 8

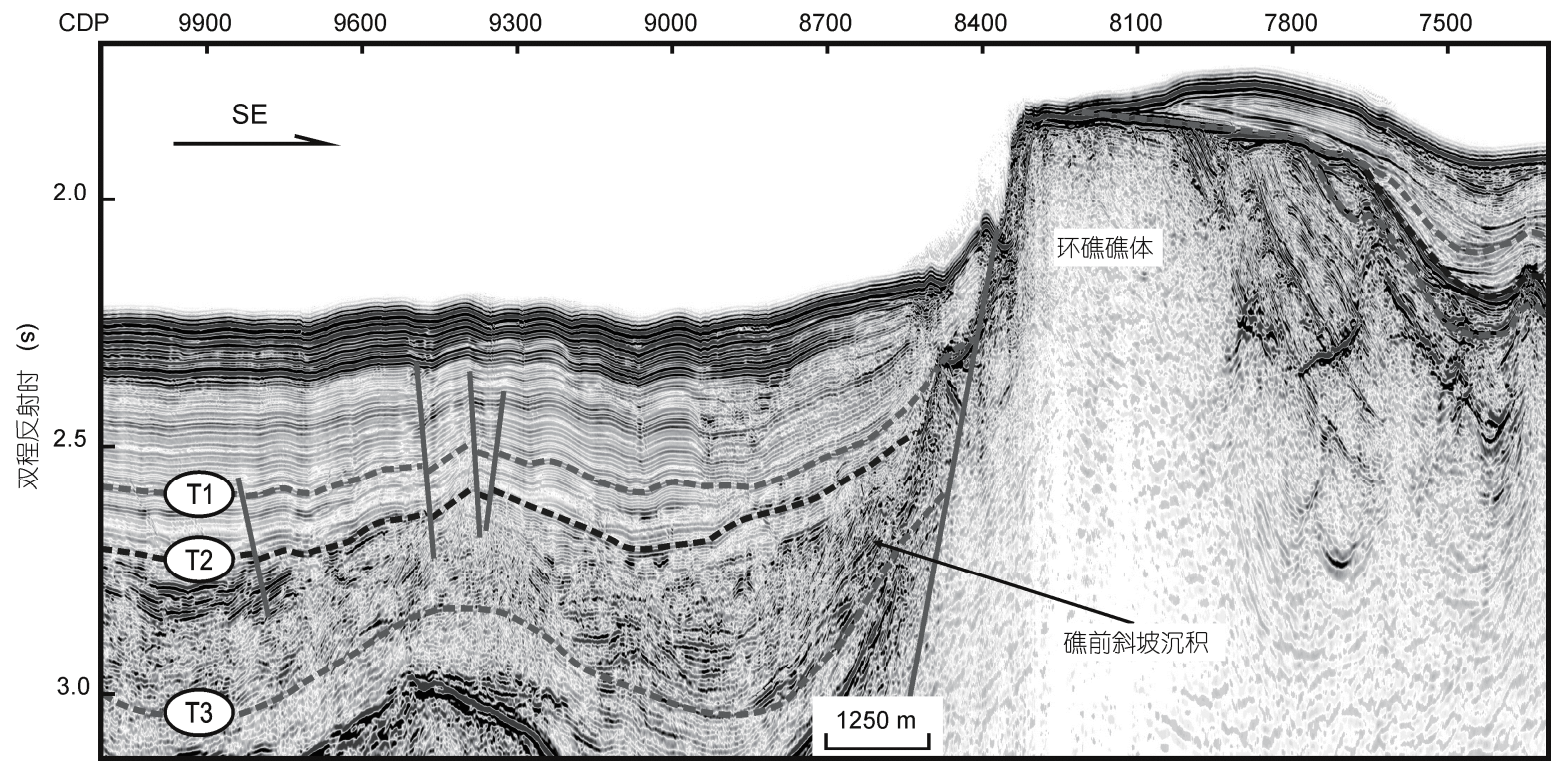

图 12 环礁体系 $\mathbf{C}$ 的淹没

注意礁前斜坡沉积只发育于 $\mathrm{T} 3$ 与 $\mathrm{T} 2$ 界面之间的地层中, 这表明环礁体系 $\mathrm{C}$ 在上新世就被淹没. 位置见图 8

对海平面上升包括了全球海平面上升及构造沉降, 但是全球海平面升降基本在 $300 \mathrm{~m}$ 左右来回震荡, 因 此构造沉降基本上控制了研究区内的相对海平面上 升, 从而也总体上控制了研究区内生物礁的生长及 淹没, 但是全球海平面升降在一个短期时间内对生 物礁的生长仍然存在影响, 如图 4 所示的大型环礁礁 体上发育了喀斯特地貌形态, 这表明在这一时期, 全 球海平面下降速度超过了构造沉降的速度, 致使短
时期内出现相对海平面下降, 环礁礁体出露海表, 遭 受雨水的风化淋滤, 环礁礁体也停止生长.

总的来看, 从晚中新世至现今, 研究区所在海域 相对海平面总体处于上升阶段, 但偶尔也会出现相 对海平面下降, 晚中新世发育的环礁经历了两次溺 礁事件, 至今已全部没于海底之下, 环礁的生长与淹 没长期来看主要受构造沉降控制, 全球海平面升降 在短期的某一时段内也会产生影响. 

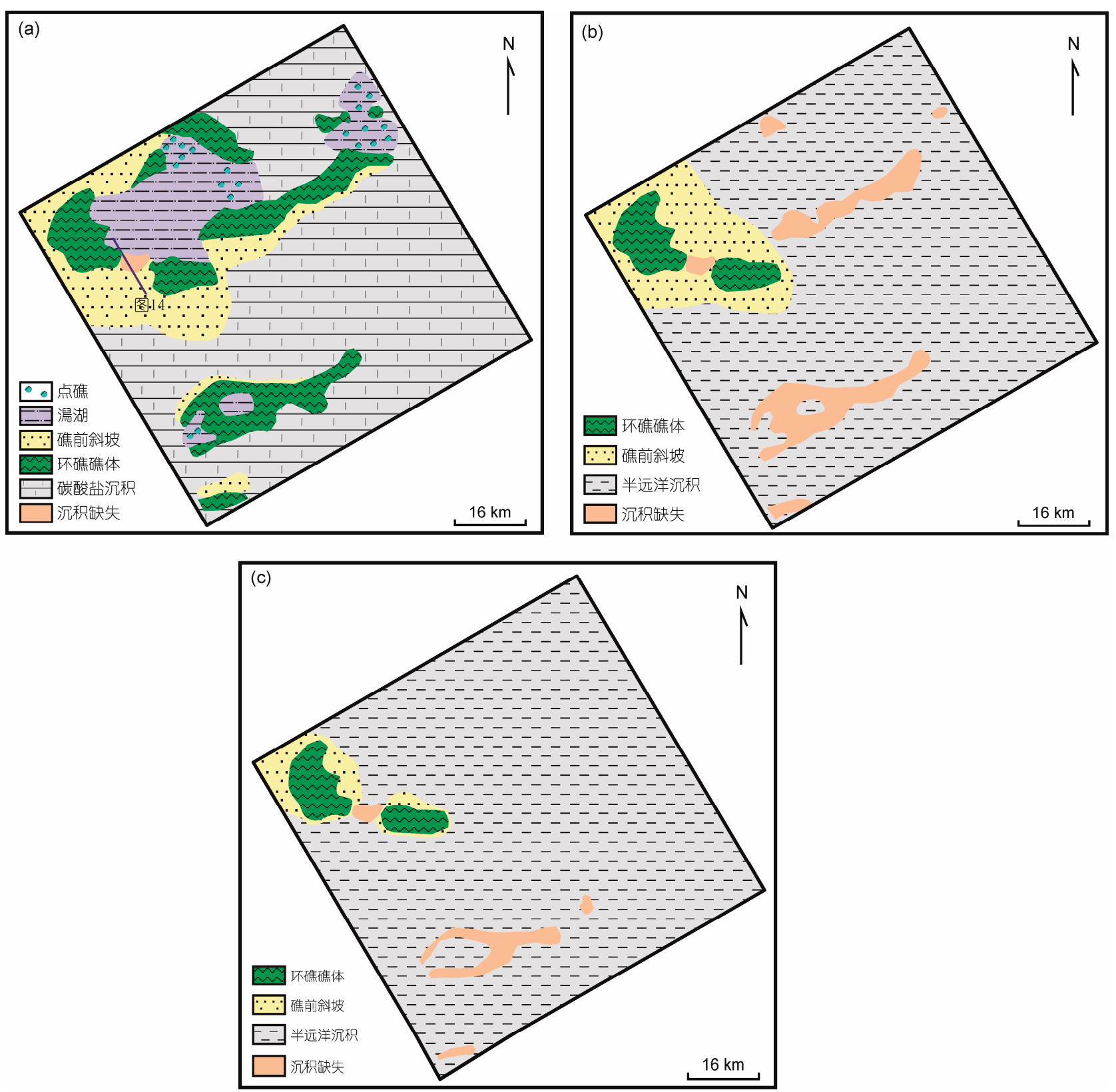

图 13 晚中新世以来环礁体系的时空演化

(a) 晚中新世; (b) 上新世; (c) 第四纪

\section{7 结论}

(1) 在西沙海域发现了 3 个晚中新世环礁体系, 均发育于由断层控制的地垒之上, 内部发育环礁礁 体、点礁、礁前斜坡及潟湖沉积, 这三个环礁体系分 别处于环礁发育的幼年、壮年及老年期.

(2) 在层序地层框架下根据礁前斜坡沉积的发
育来判断环礁体系的淹没史：环礁体系 $\mathrm{A}$ 的大型环 礁礁体一直持续发育至第四纪才最终淹没, 环礁体 系 $\mathrm{B}$ 和 $\mathrm{C}$ 均在上新世就被淹没.

（3）晚中新世环礁体系发育最为广泛和完整，表 明晚中新世是西沙海域造礁生物最为繁盛的一个时 期, 环礁体系主要占据了断层控制的构造高部位, 而 深海碳酸盐沉积则广泛分布于 3 个环礁体系之间的 


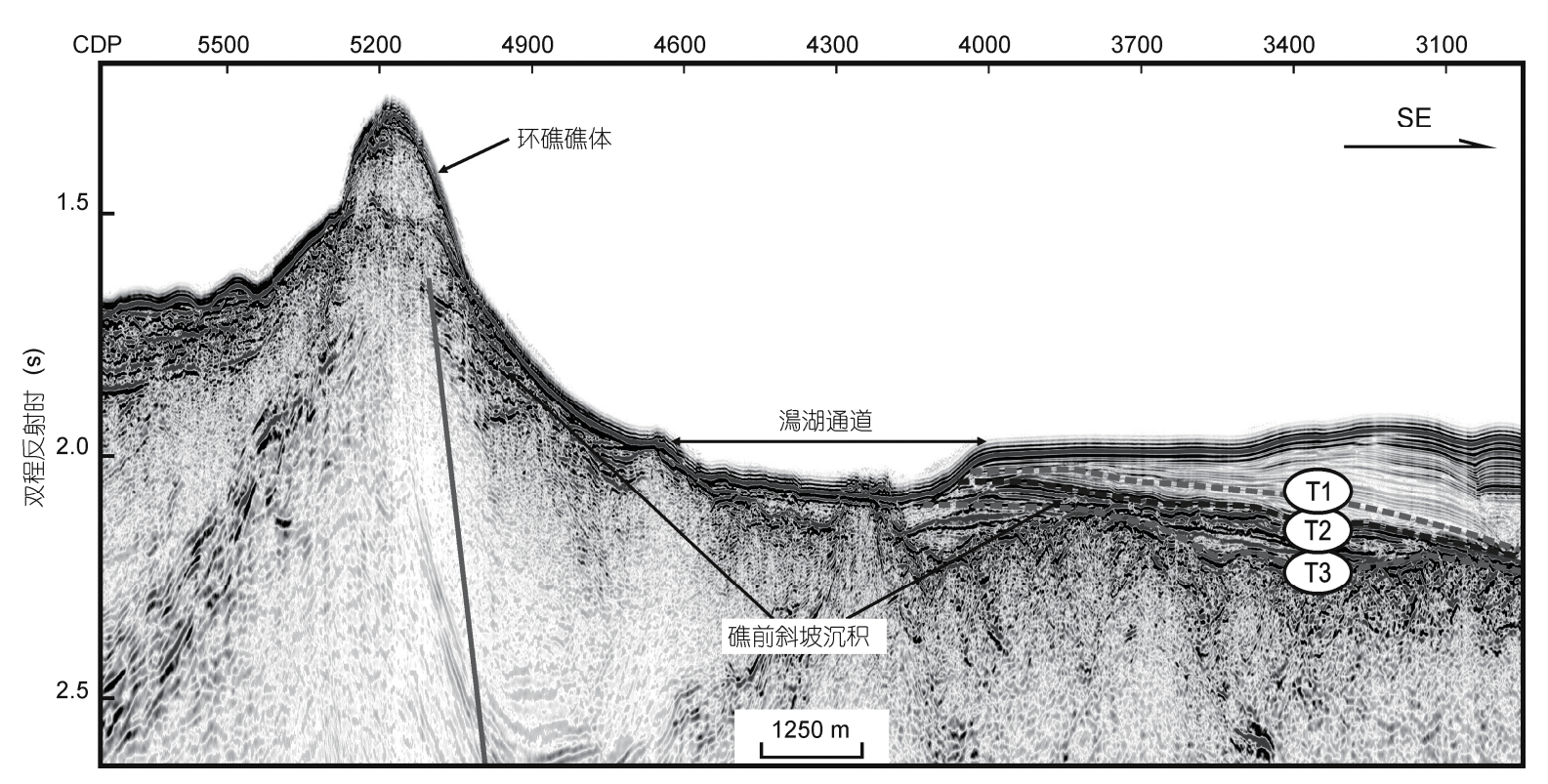

图 14 潟湖通道形态

位置见图 13(a)

区域. 上新世是研究区内一个重要的生物礁淹没期, 环礁体系 B 及 $\mathrm{C}$ 全部被淹没于海水之下, 只有环礁体 系 $\mathrm{A}$ 上的两个大型环礁礁体持续发育, 生物礁逐渐 萎缩, 半远洋沉积开始占据优势. 第四纪是研究区内 另一个生物礁淹没期, 环礁体系 $\mathrm{A}$ 上的两个大型环
礁礁体虽在第四纪某个时期内仍在继续生长, 但最 终被淹没于海底之下, 半远洋沉积开始覆盖填平晚 中新世形成的环礁体系.

（4）环礁的生长与淹没长期主要受构造沉降控制, 全球海平面升降在短期的某一时段内也会产生影响.

致谢

感谢广州海洋地质调查局允许将此文发表. 审稿人提出了非常有建设性的意见, 本文在行文过程中得到了同 济大学海洋学院钟广法教授的悉心指导, 在此一并表示衰心的感谢.

\section{参考文献}

何起祥, 张明书. 1986. 中国西沙礁相地质. 北京: 科学出版社. 1-182

黄鸿光, 陆永潮, 邹卓超, 等. 2012. 琼东南盆地松南三维区台缘礁地震沉积学研究. 石油实验地质, 34: 25-29

黄金森. 1987. 中沙环礁特征. 海洋地质与第四纪地质, 7: 21-24

姜在兴. 2003. 沉积学. 北京: 石油工业出版社. 415

刘宝珺. 1980. 沉积岩石学. 北京: 地质出版社. 432

马玉波, 吴时国, 张功成, 等. 2009a. 南海北部陆缘深水区礁相碳酸盐岩的地球物理特征. 中国石油大学学报(自然科学版), 33: 33-39

马玉波, 吴时国, 许建龙, 等. 2009b. 琼东南盆地南部深水凹陷生物礁及碳酸盐岩台地发育模式. 天然气地球科学, 20: 119-124

马玉波, 吴时国, 谷明峰, 等. 2010. 西沙海区碳酸盐台地地震反射特征及沉积模式. 海洋学报, 32: 118-128

马玉波, 吴时国, 杜晓慧, 等. 2011. 西沙碳酸盐岩建隆发育模式及其主控因素. 海洋地质与第四纪地质, 31: 59-67

聂宝符, 陈特固, 梁美桃, 等. 1996. 近百年来南海北部珊瑚生长率与海面温度变化的关系. 中国科学 D 辑: 地球科学, 26: 59-66 孙珍, 孙龙涛, 周蒂, 等. 2009. 南海岩石圈破裂方式与扩张过程的三维物理模拟. 地球科学一一国地质大学学报, 34: 435-447 王国忠, 吕炳全, 全松青, 等. 1988. 一个大陆坡环礁一一南海华光珊瑚环礁的沉积相模式及其演化趋势. 同济大学学报, 16: 149-158 吴时国, 袁圣强, 董冬冬, 等. 2009. 南海北部深水区中新世生物礁发育特征. 海洋与湖沼, 40: 117-121

杨涛涛, 吕福亮, 王涁, 等. 2011. 西沙海域生物礁地球物理特征及油气勘探前景. 地球物理学进展, 26: 1771-1778 
余克服. 2012. 南海珊瑚礁及其对全新世环境变化的记录与响应. 中国科学：地球科学, 42: 1160-1172

袁圣强. 2009. 南海北部陆坡区深水水道沉积体系研究. 博士学位论文. 青岛: 中国科学院海洋研究所. 64

曾昭璇. 1982. 中国环礁的类型划分. 海洋通报, 4: 43-50

曾昭璇. 1984. 南海环礁的若干地貌特征. 海洋通报, 3: 40-45

曾昭璇, 丘世钧. 1985. 西沙群岛环礁沙岛发育规律初探一以晋卿岛、琛航岛为例. 海洋学报, 7: 472-483

赵焕庭, 温孝胜, 王丽荣. 2000. 南沙群岛永暑礁环礁泻湖的沉积速率与气候变化. 热带地理, 20: 247-249

赵强. 2010. 西沙群岛海域生物礁碳酸盐岩沉积学研究. 博士学位论文. 青岛: 中国科学院海洋研究所. 1-158

Briais A, Patriat P, Tapponnier P. 1993. Updated interpretation of magnetic anomalies and seafloor spreading in the South China sea: Implications for the Tertiary tectonics of Southeast Asia. J Geophys Res, 98: 6299-6328

Li J R, Wang P X. 2009. Sedimentology-Carbonate. In: Wang P X, Li Q Y, eds. The South China Sea: Paleoceanography and Sedimentology. Berlin: Springer. 204-217

Ma Y B, Wu S G, Lv F L, et al. 2011. Seismic characteristics and development of the Xisha carbonate platforms, northern margin of the South China Sea. J Asian Earth Sci, 40: 770-783

Read J E. 1985. Carbonate platform facies models. AAPG Bull, 69: 1-21

Wang P X, Prell W L, Bleum P, et al. 2000. Proceedings of the Ocean Drilling Program. Initial Reports Volume 184. 2

Wei G J, Sun M, Li X H, et al. 2000. Mg/Ca, Sr/Ca and U/Ca ratios of a porites coral from Sanya Bay, Hainan Island, South China Sea and their relationships to sea surface temperature. Paleogeogr Paleoclimatol Paleoecol, 162: 59-74

Wilson M E J. 2002. Cenozoic carbonates in Southeast Asia: Implications for equatorial carbonate development. Sediment Geol, 147: 295-428

Wu S G, Yuan S Q, Zhang G C, et al. 2009. Seismic characteristics of a reef carbonate reservoir and implications for hydrocarbon exploration in deepwater of the Qiongdongnan Basin, northern South China Sea. Mar Pet Geol, 26: 817-823

Yu K F, Zhao J X, Collerson K D, et al. 2004a. Storm cycles in the last millennium recorded in Yongshu Reef, southern South China Sea. Paleogeogr Paleoclimatol Paleoecol, 210: 89-100

Yu K F, Zhao J X, Liu T S, et al. 2004b. High-frequency winter cooling and reef coral mortality during the Holocene climatic optimum. Earth Planet Sci Lett, 224: 143-155 